\title{
ROLA IMIENIA WE WCZESNOSZKOLNYM NAUCZANIU JĘZYKÓW NIERODZIMYCH
}

\author{
KAROLINA ADRYAN
}

\begin{abstract}
The article focuses on the effectiveness of the name-based method (Odimienna Metoda Nauki Czytania) developed by Irena Majchrzak in foreign language teaching to young pupils. Children's names prove a good starting point for learning to read in a foreign language. As a valuable educational material of emotional charge, the name constitutes an integral part of the learner and thus can be used as a personalised primer containing a basic text to be the first read by children. Originally used to teach reading in Polish kindergartens, the name-based method may inspire teachers in teaching a foreign language to young learners as an ingenious pedagogical innovation. My professional experience indicates that the reading skills in a foreign language in the first stage of education are underestimated. My data come from a six-month experiment in a primary bilingual school where I introduced the name-based method. As a result, the children's own names in their foreign language versions provided an excellent educational basis. The conclusions reveal that this method helps in expanding vocabulary, developing linguistic sensitivity, stimulating communication skills, and positively affecting language fluency.
\end{abstract}

Key words: names, identity, the name-base method, emotions, glottodidactics, pedagogical innovations

\section{Wstęp}

Onomastyka to dział nauki zajmujący się badaniem pochodzenia nazw własnych, ich klasyfikowaniem oraz budową słowotwórczą lub gramatyczną wyrazów w celu odróżnienia nazw własnych od pospolitych. Słowo onomastyka pochodzi od greckiego terminu onoma oznaczającego imię (Szczerbowska-Kopacz 2011: 177). Imiona ludzkie są tak niezwykłymi nazwami własnymi osobowymi, że doczekały się własnej gałęzi onomastyki, działu zajmującego się ich badaniem - antroponimii. Czy imię definiuje człowieka? Czym kierują się rodzice przy wyborze imienia? Jak reaguje ludzki mózg na własne imię? I wreszcie, czy imię i uczenie się mają ze sobą 
coś wspólnego? Pierwsza część artykułu oscyluje wokół psychologicznych aspektów imion ludzkich oraz uwarunkowań społeczno-kulturowych podczas ich nadawania. Poruszona tu problematyka to implikacje: imię a jakość życia. Kolejna część artykułu to rola imienia w nabywaniu tożsamości przez jednostkę oraz reakcja mózgu na własne imię. W dalszych częściach zdefiniowane zostały współczesne podejścia dydaktyczne dotyczące nauki czytania oraz miejsce Odimiennej Metody Nauki Czytania Ireny Majchrzak wśród wiodących metod. Niniejszy artykuł jest próbą analizy efektywności zastosowania imienia i związanych z nim emocji $\mathrm{w}$ procesie nauki czytania w języku ojczystym i obcym.

\section{Wybór imienia a jakość życia}

Dokonując wyboru imienia dla swojego dziecka rodzice zazwyczaj poszukują, $\mathrm{w}$ ich mniemaniu, tego najbardziej odpowiedniego. Często kierują się przekonaniem, że każde imię niesie ze sobą bagaż określonych cech, pożądanych zachowań i pozytywnie wpływa na życie właściciela. Jest to tak zwane „myślenie magiczne” charakteryzujące procesy archaiczne i prymitywny pogląd na świat (Samochowiec i in. 2004: 19). Z drugiej strony, myślenie magiczne choć znane ludziom od dawna dotyczy głównie dzieci, ale w pewnych formach pojawia się także u ludzi dorosłych, zwłaszcza wśród ludów pierwotnych lub jednostek niewykształconych. Doroszewicz (2003: 89) w swoich badaniach przywołuje przysłowia łacińskie „,nomina sunt omina" - oznaczające, że imiona są wróżbami, czy łacińską maksymę przekonującą, że w imieniu jest wróżba - „nomen est omen”.

Podobne stanowisko prezentuje Postoła (2012), która w swoim artykule pt. „Klątwa Dżastina, czyli magia imion” przedstawia historię braci urodzonych w Stanach Zjednoczonych na przełomie lat 50 i $60 \mathrm{XX}$ w. Starszy z braci otrzymał imię „Winner” (pol. Zwycięzca), a młodszy „Loser” (pol. Frajer/ Przegrany), przy czym wbrew konotacyjnemu znaczeniu imion, to właśnie ten drugi osiągnął w życiu sukces. Loser Lane ukończył college i uzyskał stopień sierżanta pracując w nowojorskiej policji, natomiast Winner Lane dał się poznać jedynie z działalności kryminalnej oraz wielu wykroczeń. Warto dodać, że imiona zostały nadane przez ojca, a imię drugiego z chłopców nie wynikało z niechęci do dziecka, a stanowiło raczej przeciwwagę, czy może rodzaj równowagi wobec imienia Winner. Autorzy Freakonomics (Levitt i Dubner 2005: 164) opisujący wspomniane wyżej zdarzenie w swojej książce nazywają to zjawisko name's bookend effect (pol. podpórka). Dodatkowo, imię Loser nie przyjęło się wśród osób z otoczenia chłopca. Używanie tego imienia wobec młodego człowieka brzmiało obraźliwie i wywoływało dyskomfort, aż w rezultacie zastąpiono je innymi popularnymi imionami. Levitt i Dubner (2005: 165) podają kolejne przykłady kontrowersyjnych imion powołując się na doświadczenia sędziego Sądu Rodzinnego w Nowym Jorku W. Denis'a Duggan'a, który w swojej 
praktyce niejednokrotnie spotkał się z obywatelami noszącymi takie imiona, stającymi przed sądem z powodu wykroczeń. Istotne zdaje się być pytanie: czy los tych ludzi był wynikiem imienia, czy raczej imiona były wynikiem nieudolnej opieki rodzicielskiej, która w końcu doprowadziła młodych przed oblicze sądu? Zatem, imię może nie tyle ma wpływ na życie, ale jest odzwierciedleniem życia, a w fazie początkowej odzwierciedleniem życia rodziców.

Levitt i Dubner (2005: 166) przywołują badania prowadzone współcześnie w Stanach Zjednoczonych przez wybitnego ekonomistę Roland'a G. Fryer'a Jr., skupiającego się na ekonomicznych i społecznych różnicach występujących między białymi i czarnoskórymi obywatelami. W rezultacie odkrył, że obie grupy prowadzą różny tryb życia, preferują inne rozrywki, a nawet nadają dzieciom typowe dla siebie imiona. Dodatkowo, badając akty urodzenia kalifornijskich dzieci, począwszy od tych z lat sześćdziesiątych XX wieku, Fryer Jr. stwierdził jednoznacznie, że rozdźwięk pomiędzy imionami białych Amerykanów i Afroamerykanów jest coraz większy, zwłaszcza wśród imion nadawanych dziewczynkom. Rodzicem, który daje wyraźnie czarne imię (ang. distinctively black name) (Levitt i Dubner, 2005: 168) najczęściej jest uboga, niezamężna i słabo wyedukowana nastoletnia matka, solidaryzująca się ze swoją społecznością, a jednocześnie nosząca również imię popularne w jej otoczeniu. Z kolei, druga strona społeczeństwa uznana z racji koloru skóry za biała akcentuje swoje pochodzenie w podobny sposób.

\section{Stereotypy dotyczące imion}

Nasuwa się pytanie, czy fakt, że społeczeństwo nadaje różne imiona charakterystyczne dla swojej grupy etnicznej ma wpływ na jej postrzeganie przez nieświadomą tego stanu rzeczy część społeczeństwa? Czy to aktywuje stereotypy o podłożu rasowym? Dane zebrane przez badaczy z Massachusetts Institute of Technology pokazują, że listy motywacyjne wysłane do potencjalnych pracodawców z okolic Bostonu i Chicago podpisane imionami charakterystycznymi dla białej części społeczeństwa amerykańskiego spotykały się z zainteresowaniem większym o $50 \%$ ze strony pracodawców niż te wskazujące na aplikujących Afroamerykanów. Kwalifikacje potencjalnych pracowników nie miały w początkowej fazie procesu rekrutacji najważniejszego znaczenia (Doroszewicz i Krzemińska 2007: 260). Powyższe badania wskazują na aktywizowanie się za pośrednictwem imion stereotypów o charakterze rasowym. Doroszewicz i Krzemińska (2007: 260) w swojej rozprawie przekonują, że imię to „element autoprezentacji”, na podstawie którego wnioskowana jest nie tylko narodowość czy rasa, ale również wiek, płeć i przewidywane elementy osobowości. Przy czym, wpływ na postrzeganie jednostki ma nie tylko imię, ale również jego forma, która może być oficjalna, skrócona lub pieszczotliwa. Zatem „różne odmiany tego samego imienia niosą specyficzne konotacje emocjonalne ze strony 
otoczenia i każda z form zawiera inny przekaz" (Doroszewicz i Krzemińska 2007: 262), który będzie zredukowany przypadku imion zubożałych do jednej formy (oficjalnej), albo występującej powszechnie (zdrobniałej). Badania przeprowadzone w Polsce na grupie studentów Wyższej Szkoły Zarządzania i Marketingu w Warszawie przez Doroszewicz i Krzemińską (2007: 268-269) jednoznacznie potwierdziły, że nie tylko imię, ale również jego forma łączy się znacząco z cechami osobowości. Imiona $\mathrm{w}$ wersji oficjalnej były częściej wybieranie $\mathrm{w}$ kontekście moralności, sukcesu oraz własnej kobiecości i męskości, natomiast imiona w formie potocznej występowały w odniesieniu do okoliczności o charakterze towarzyskim.

\section{Imię a tożsamość}

Potwierdzeniem tezy, że imię i nazwisko ma wpływ na postrzeganie danej jednostki jest choćby trend polegający na zmianie imienia bądź nazwiska występujący wśród osób znanych. I tak, osoby, których kariera nabrała tempa po zmianie, to np. Pola Negri - wcześniej Apolonia Chałupiec, Marlin Monroe - Norma Jean Baker, Violetta Villas - Czesława Gospodarek i wreszcie postać współczesna, Olivier Janiak - urodzony jako Piotr Michał Janiak. Warto zauważyć, że użytkownik danego imienia nie zawsze musi dokonywać drastycznych zmian. Fakt, iż większość imion może występować w różnorodnych formach pozwala na ich subtelne przeistoczenia poprzez używanie form najbardziej satysfakcjonujących, które podkreślą pożądane cechy w danej sytuacji bądź grupie społecznej (Doroszewicz i Krzemińska 2007: 263).

Hodson i Olson w swoim artykule (2004) poświęconym teorii ,name letter effect" nie wykluczają możliwości przejawiania pozytywnego stosunku wobec liter występujących we własnym imieniu lub nazwisku bądź ich wpływie na wybór ścieżki kariery, partnerów czy produktów. Zatem, skoro nawet możliwy jest ścisły związek z literami, to jak bliski jest związek z własnymi imionami? Imię jest jednym z pierwszych wyrazów jakie dziecko poznaje, uczy się wymawiać a w dalszym procesie poznania - pisać. Rozwój tożsamości przebiega wielotorowo od pierwszych dni dziecka. Początkowo jest to nadanie imienia oraz wpływ najbliższych opiekunów, który z czasem powiększa się o następne aspekty oraz rozszerza o wpływ kolejnych osób. Dziecko poznaje siebie i świat równolegle poprzez zdobywanie doświadczeń i stymulację zewnętrzną. Czub (2014: 20) podkreśla, że wzrost autonomii następuje w okresie poniemowlęcym, a rozwój samoświadomości przejawia się $\mathrm{w}$ postępach $\mathrm{w}$ rozwoju poznawczym i rozpoznawaniu siebie $\mathrm{w}$ lustrze. Małus (2016: 29) pisze o tym w następujący sposób:

Gordon Allport akcentuje wagę imienia w kształtowaniu się samoświadomości. Niemowlę traktuje swoje ciało - jakby było ono mu obce - nie ma cielesnego ja, socjalnego $j a$, materialnego ja. Granica między ja i nie-ja oraz moje i nie-moje jest jeszcze nie wytyczona, dziecko nie posiada - jakby to powiedział Koffka - organizacji ja. Organizacja 
ja pojawia się stopniowo wraz z procesem mentalizacji (...) czy z rozwojem języka. (...) Imię staje się coraz bardziej punktem strategicznym kontaktów między ja i światem zewnętrznym (Małus 2016: 29).

Badania na dzieciach adopcyjnych, poznających prawdę o swoim statusie w rodzinie, przeprowadzone przez Haimes (Małus 2016: 29) jednoznacznie wskazują, że w przypadku tych, u których zmieniono nie tylko nazwisko, ale również imię często dochodzi do konfliktu intrapersonalnego. Dzieci te nie tylko czują stres związany $\mathrm{z}$ ujawnieniem ich sytuacji, nie tylko zmagają się z problemem odnalezienia w rodzinie, którą do tej pory uznawały za biologiczną, ale jednocześnie mają wrażenie posiadania fałszywego życiorysu, co jest przyczyną wewnętrznych sprzeczności przekonań i wartości jednostki będących początkiem kryzysu tożsamości, prowadzącego $z$ reguły do powrotu do imion nadanych im pierwotnie przez biologicznych rodziców.

\section{Imiona dawne i współczesne}

Nadanie imienia, czyli nazwy indywidualnej przez opiekunów w akcie religijnym jakim jest chrzest, albo w akcie administracyjnym, oznaczało według onomastyki semickiej poznanie i otoczenie władzą przez dorosłych nowonarodzonej jednostki społecznej jaką jest dziecko. Zatem, zaznajomienie się z czyimś imieniem było równoznaczne z przejęciem kontroli nad czyimś życiem. W związku z tym, w prastarych kulturach używano dwóch imion: wielkich stanowiących tabu oraz małych - publicznych (Małus 2016: 26-27). Imię ściśle połączone z tożsamością nadawało człowiekowi miejsce w hierarchii grupy. Nasi przodkowie nadawali imiona, które wskazywały na cechy fizyczne lub psychiczne charakterystyczne dla dziecka, np. Smetek, Matuł czy Zwinka lub oczekiwane i chętnie „dziedziczone” po danym obiekcie lub bóstwie (Doroszewicz 2003: 89). Z drugiej strony, w staropolskich zwyczajach imiona pełniły również dodatkową funkcję ochronną. Małus (2016: 27) przekonuje, że według pradawnych wierzeń prawdopodobnie wszelkie nazwy własne związane $\mathrm{z}$ ogniem miały wprowadzać w błąd złe moce i demony odpowiedzialne za choroby. Podobne zadanie pełniły w kulturze chrześcijańskiej imiona Boga, świętych czy Maryi.

Warto wspomnieć, że nazwiska pojawiające się w historii później niż imiona, które przestały wystarczać do identyfikacji mieszkańców w obrębie znacząco rozwijających się miast, były narzędziem wykorzystywanym w walce z represjami politycznymi. Koole i Pelham (2002: 93) wspominają ciekawą historię sięgającą rządów Napoleona w roku 1811, kiedy to wydany przez niego dekret zobowiązywał Duńczyków do rejestrowania nazwisk rodowych. Niechętni Napoleonowi mieszkańcy protestowali chcąc wyrazić swoją dezaprobatę wobec władzy, wymyślając dla siebie 
samych często dziwne i ośmieszające nazwiska, takie jak Naaktgeboren - „Urodzony Nagi”, czy Den Boef - „Oszust”.

Oczywiście tendencje kulturowe w nadawaniu imion podlegają ciągłej zmianie, co zaobserwowała Maria Czaplicka-Jedlikowska (2008: 107) w swoich badaniach prowadzonych u schyłku XX wieku na terenie obecnego województwa KujawskoPomorskiego. Na podstawie analizy zebranego materiału, wysnuła ona wniosek, że motyw dominujący przy wyborze imienia dla dziecka to preferencje rodziców nakierowane na wybór imienia popularnego i modnego, nierzadko inspirowanego kulturą masową, mającego europejski odpowiednik.

\section{Reakcja mózgu}

Badaniem mózgu i jego reakcją na imię i nazwisko zajęli się naukowcy z Instytutu Biologii Doświadczalnej im. M. Nenckiego PAN w Warszawie (Zagórski 2010). Anna Nowicka i Paweł Tacikowski zaprosili do badania 30 praworęcznych ochotników w wieku od 22 do 38 lat. Każdemu uczestnikowi zaprezentowano w sumie 240 plansze. Część plansz przedstawiała własne imię i nazwisko (60 tablic), kolejne plansze (60 sztuk) - imiona i nazwiska osób znanych publicznie, natomiast pozostałe zawierały dane personalne zupełnie przypadkowych, nieznanych osób. Z badań wynika, że reakcja mózgu na własne imię była szybsza i silniejsza. Rozpoznanie własnych imion czy nazwisk zabierało o 200 milisekund czasu mniej niż reakcja na pozostałe personalia, czyli około 500-600 milisekund. Kolejnym etapem było przeprowadzenie analogicznego doświadczenia $\mathrm{z}$ tablicami prezentującymi twarze. Podobnie jak wcześniej, na sześćdziesięciu znajdowało się zdjęcie własnej podobizny, na kolejnych sześćdziesięciu obrazy osób powszechnie znanych, a pozostałe ilustrowały nieznane twarze przypadkowych osób. Mózg ludzki znowu szybciej i mocniej reagował na własną podobiznę. Badania kontynuowane były w Instytucie Neurobiologii w Magdeburgu z naciskiem na rozpoznanie ośrodków i struktur mózgowych odpowiedzialnych za reakcję. Udowodniono, że prawy dolny zakręt czołowy, czyli miejsce zaangażowane w procesy uwagi reaguje intensywniej na własne personalia i wizerunek w odróżnieniu od tych dotyczących innych osób, zarówno przypadkowych, bliskich czy szeroko znanych opinii publicznej.

\section{Odimienna Metoda Nauki Czytania}

Wspomniane badania przeprowadzone przez Nowicką i Tacikowskiego sprawiły dużo satysfakcji Irenie Majchrzak, twórczyni Odimiennej Metody Nauki Czytania. Potwierdziły bowiem, że człowiek znacznie szybciej reaguje na własne imię i tym samym wskazały istotę i ważność własnego imienia w życiu człowieka. Swoimi 
przemyśleniami Majchrzak podzieliła się na łamach czasopisma „Bliżej Przedszkola" (Halik 2010), stwierdzając, że publikacja sprawozdania z badań Nowickiej i Tacikowskiego na łamach „Gazety Wyborczej” stanowiły pośrednio ważny aspekt również jej życia naukowego. Dotąd ta propozycja metodyczna nie cieszyła się zainteresowaniem w żadnym z ośrodków akademickich, natomiast badania opublikowane przez naukowców z PAN mogły wpłynąć również na pozytywne postrzeganie metody odimiennej przez środowiska uniwersyteckie.

Irena Majchrzak była przede wszystkim socjologiem. W książce na temat stworzonej przed siebie metody stwierdziła, że pedagogiem stała się przypadkowo w wyniku ,wielkiej przygody, jaką był (...) wieloletni pobyt w Meksyku” (Majchrzak 1999: 5). W latach 60 XX wieku, po uzyskaniu doktoratu w Instytucie Socjologii i Filozofii wraz z mężem dyplomatą udała się na placówkę do Meksyku, gdzie oddała się badaniom socjologicznym wśród Indian. Mimo, że tę pracę przerwał powrót do kraju, to kolejny wyjazd w czasie stanu wojennego zaowocował współpracą z rządem meksykańskim, natomiast Majchrzak - będącej osobą tzw. „z zewnątrz", bezstronną i niezwiązaną ideologicznie z meksykańskim ministerstwem oświaty - została powierzona ocena wprowadzanej tam nowatorskiej metody polegającej na przekazaniu indiańskich uczniów w ręce indiańskich nauczycieli (Majchrzak 1999: 6). Raport zawierający obserwacje i spostrzeżenia, spisany w formie listów do autora reformy Salomona Nahmada, został dostrzeżony przez żonę gubernatora prowincji Tabasco - pisarkę Juliettę Campos - odpowiedzialną za rozwój kulturalno-oświatowy tego stanu. Propozycja, którą Campos złożyła Majchrzak, obejmowała możliwość stworzenia autorskiego programu oświatowego dla indiańskich dzieci z plemienia Czontali oraz opiekę nad czternastoma internatami. Pobyt Majchrzak w jednej z podległych jej placówek i spotkanie ośmioletniej dziewczynki, którą bezskutecznie próbowała nauczyć czytać zaowocował stworzeniem metody odimiennej. Majchrzak podzieliła się obserwacją, że mimo iż dziecko doskonale znało litery, nie potrafiło dokonać syntezy wyrazów, jednocześnie ulegając coraz większemu zniechęceniu. Majchrzak (1999: 14) relacjonuje to w następujący sposób:

Siedziałyśmy przez chwilę spokojnie, świadome przeżycia ważnego i nieoczekiwanego dla nas obu wzruszenia. Dopiero po chwili na oddzielnych karteczkach napisałam wszystkie litery imienia Simona i poprosiłam, by je poskładała i ułożyła w swoje imię. Uczyniła to kilka razy z wyrazami wyraźnego zafascynowania. (...) Nasza zabawa była pełna nowych, nieoczekiwanych znaczeń, poruszających wyobraźnię i wyzwalających silne emocje, które towarzyszą narodzinom poczucia własnej tożsamości (Majchrzak 1999: 14).

Spotkanie z Simoną było zaczątkiem Odimiennej Metody Nauki Czytania, a akt inicjacji stał się pierwszym i być może najważniejszym jej etapem. Dla Majchrzak oczywistym był fakt, iż imię niesie ze sobą ogromny ładunek emocjonalny i zdecydowanie przewyższa swoją wartością elementarze służące doskonaleniu nauki czy- 
tania. Imię nie tylko bazowało na emocjach, ale jednocześnie indywidualizowało proces nauczania, ponieważ to litery występujące we własnych personaliach decydowały o tym, które znaki są najbardziej istotne dla dziecka w początkowej fazie nauki.

Doświadczenia zdobyte przez Majchrzak wpłynęły na stworzenie metody, która podzieliła proces dydaktyczny na kilka etapów. Pierwszym jest wspomniana wyżej tzw. „Inicjacja” polegająca na stworzeniu intymnej atmosfery i bezpośrednim kontakcie z nauczycielem, kiedy to dziecko teoretycznie po raz pierwszy zauważa istotę i ważność własnego imienia. Imiona zapisywane na paskach papieru, tzw. wizytówkach, stanowią doskonały materiał do zabaw, podczas których dzieci uczą się rozpoznawać własne oraz obce imiona, czytając wyrazy globalnie, całościowo. Kolejna faza nazwana „Ścianą pełną liter” polega na przedstawieniu wychowankom alfabetu. Majchrzak nie skupia się na zaprezentowaniu liter w izolacji, ale wskazuje na różne brzmienie w rozmaitych wyrazach, kładąc szczególny nacisk na dwuznaki. Dodatkowo, dziecko początkowo skupia się na literach dobrze znanych, a następnie zauważa, że te uznane za trudniejsze znajdują się w poznanych wcześniej imionach kolegów i koleżanek. „Targ liter” - trzeci etap - jest tym najbardziej skoncentrowanym na zabawie. Dzieci nie tylko utrwalają poznane znaki, ale zmuszone są współpracować z innymi wymieniając litery ze swojego imienia lub jego wariantów, np. zdrobnień, na te występujące $\mathrm{w}$ imionach pozostałych dzieci, czyli tzw. „kontrahentów”. Majchrzak (1999: 36) przekonuje, że jest to przełomowy moment, w którym uwaga wychowanków skupiona początkowo na własnych literach teraz zwraca się w kierunku tych mniej znanych, bądź do tej pory nieużywanych. Wreszcie ostatni etap „Nazywanie Świata” polega na nadawaniu przedmiotom z najbliższego otoczenia pisemnych reprezentacji. Dzieci zaopatrzone w bazę 80-100 słów zapisanych na paskach papieru w podobny sposób jak wcześniej dopasowywały imiona do poszczególnych osób, teraz zaczynają kojarzyć nazwy z przedmiotami. Z upływem czasu baza zostaje wzbogacona o kolejne wyrazy i ilustracje będące odpowiednikiem pojęć abstrakcyjnych bądź części mowy, które nie sposób zilustrować obiektem znajdującym się w najbliższym otoczeniu. Zadania stawiane przez dziećmi mają różny stopień trudności, począwszy od dwóch obiektów i wyrazów, po większą liczbę słów i przedmiotów bądź ilustracji; a dzieci finalnie odczytują wyrazy podobne, różne w brzmieniu, słowa krótkie i dłuższe.

Metoda odimienna na stałe zagościła w polskich przedszkolach, gdzie z powodzeniem jej początkowe etapy stosowane są nawet w grupach najmłodszych. Dziemianko (2015: 147-148), która przeprowadziła ewaluację metody, sformułowała wyniki na łamach „Kontekstów Pedagogicznych”. Niewątpliwe zalety, na które wskazuje autorka artykułu to nabranie przez dzieci motywacji do czytania, rozbudowa zakresu pojęć, poszerzanie zasad ortografii, opanowanie umiejętności czytania przez działanie. Dziemianko zastosowała metodę w grupie 24 dzieci 6-letnich i przeprowadziła ją od września i maja. Rezultaty są zaskakujące, ponieważ aż 
23 dzieci dokonywało analizy sylabowej i głoskowej, dwudziestu wychowanków czytało ze zrozumieniem każdy rodzaj proponowanego tekstu, a tylko troje myliło znaki podobne, np. b-d, p-b, d-p, wreszcie jedno dziecko nie opanowało umiejętności czytania nawet na podstawowym poziomie. Zatem metoda, której punktem wyjścia jest imię niewątpliwie posiada ogromny potencjał edukacyjny i odwołuje się do emocji, bez których proces uczenia jest bezwartościowy.

\section{Teorie przemawiające za włączeniem metody odimiennej w proces nauczania języka obcego}

Wnioski badań empirycznych w zakresie wczesnoszkolnego nauczania języków obcych w Polsce przedstawione na łamach „Neofilologa” (Andrzejewska 2010: 138) jednoznacznie wskazują na kluczowe elementy oddziałujące na sukces procesu edukacyjnego. Oczywiście wpływ mają czynniki indywidualne, takie jak wiek, płeć, czy poziom rozwoju procesów poznawczych, ale co ważne, również dobór materiału leksykalnego. Andrzejewska (2010) powołując się na badania Wieszczeczyńskiej (2007) twierdzi, że wykorzystanie tych samych metod do nauki czytania zarówno w języku obcym, jak i ojczystym jest zasadne, ponieważ pozwala na opanowanie umiejętności na poziomie bardzo dobrym.

Pojęcie czytania angażujące szereg funkcji psychofizycznych jest szeroko rozumiane przez różnych badaczy (np. Brzezińska 1987, Malmquist 1987, Metera 1978, Cackowska 1984, Tinker 1980). Analizując kształtowanie się umiejętności czytania, Olejnik (2001) wyodrębnia trzy grupy definicji:

1) Definicje, w których proces czytania rozpoczyna się od strony lingwistycznej, podkreślają istotność utworzenia prawidłowej formy dźwiękowej na podstawie zapisu danego symbolu graficznego.

2) Definicje procesu czytania, w których jako podstawę przyjmuje się rozumienie czytanego tekstu.

3) Definicje procesu czytania, w których uwzględnia się technikę czytania, rozumienie tekstu oraz krytyczno-twórczy stosunek do tekstu.

Pierwsza grupa definicji kładzie szczególny nacisk na technikę czytania i umiejętność tworzenia dźwięków na podstawie obrazów graficznych, czyli liter. Kolejna grupa definicji podkreśla istotę rozumienia danego tekstu i nadawania treści przeczytanym wyrazom. Wreszcie ostatnia grupa skupia się rozumieniu czytania jako złożonego procesu wspólnych działań umysłowych uzależnionych od predyspozycji jednostki. Klus-Stańska (2005: 16) zauważa, że w XXI wieku podejście lingwistyczne pozostaje wciąż żywe w elementarzach, pojawiając się w zbitkach głosek pozbawionych sensu i znaczenia, bądź jako element terapii zaburzeń czytania. Wysiłki są skoncentrowane przede wszystkim na rozwinięciu słuchu fonematycznego 
poprzez ćwiczenia analizy i syntezy słuchowej wyrazów, co jest kluczowe, ale niewystarczające. Na uchybienia podejścia lingwistycznego wskazuje między innymi metoda odimienna Majchrzak, dla której wymóg głoskowania to niepotrzebna bariera, ponieważ głoski są dźwiękami nie występującymi w izolacji. Drugie podejście o szerszym znaczeniu zaprezentowane przez Klus-Stańską to podejście psychologiczne lub inaczej zwane podejściem psycholingwistycznym, gdzie:

podkreśla się złożoność, wieloaspektowość i znacznie szerszy zakres operacji językowych i poznawczych składających się na kompetencje związane z czytaniem. W takim ujęciu definicja czytania odwołuje się do trzech typów umiejętności: percepcyjnych, lingwistycznych i poznawczych. W koncepcji A. Brzezińskiej odnajdujemy je jako aspekt techniczny, semantyczny i krytyczno-twórczy (Klus-Stańska 2005: 17).

Aspekt techniczny dotyczy umiejętności rozpoznawania i łączenia grafemów z fonemami. $Z$ kolei, aspekt semantyczny to rozumienie treści, nadawanie znaczenia wyrazom i zdaniom; i wreszcie aspekt krytyczno-twórczy odnosi się do oceny czy interpretacji czytanych treści.

Pamuła (2009: 111) zwraca uwagę na rosnącą rolę umiejętności czytania w języku obcym w kontekście wzrastającej liczby migracji oraz powstawania społeczeństw wielokulturowych. W związku z tym, umiejętność czytania w języku obcym staje się właściwie równorzędna $z$ umiejętnością czytania $w$ języku ojczystym. Ma to wpływ na prowadzenie coraz większej liczby badań porównawczych wykorzystywanych podczas konstruowania efektywnych programów. Poza tym, powołując się na badania Brisk i Harrington (2007), Pamuła (2009: 113) podkreśla, że traktując czytanie jako cykl polegający na rozpoznawaniu i odkodowaniu liter, a następnie wyrazów, zdań oraz rozumieniu tekstu, „uczniowie rozwijający umiejętność czytania w dwóch językach muszą ten psycholingwistyczny proces opanować w jednym języku, a w obydwu opanować nowy system znaków, słów, gramatyki i struktury tekstu". Metody i techniki rozwijające sprawność czytania u dzieci to te, które rozwijają umiejętność rozumienia języka i dekodowania znaczeń. W skład rozumienia języka wchodzi wiedza językowa (znajomość słownictwa, kompetencje fonologiczne i świadomość struktury języka) oraz ogólna wiedza o świecie. Z kolei, dekodowanie to „znajomość alfabetu, świadomość fonologiczna, znajomość zasad relacji grafem-fonem i umiejętność połączenia warstwy pisemnej języka z językiem mówionym" (Pamuła 2009: 122). Służy temu szereg zabaw, które z powodzeniem odnaleźć można również w propozycji Ireny Majchrzak, czyli np. wykorzystanie w klasie szkolnej etykiet zawierających nazwy najbliższych sprzętów lub dobrze znanych poleceń, tworzenie z uczniami zbiorów poznanych słów (bank słów) w celu rozwijania rozumienia języka. Natomiast metody i techniki rozwijające umiejętność dekodowania to przede wszystkim ,zapoznanie uczniów z alfabetem w danym języku, zwrócenie uwagi na litery, które nie występują w języku polskim, przygotowanie kart z alfabetem (...); karty mogą być powieszone w klasie" (Pamuła 2009: 123). 
Proces czytania jest aktem żmudnym, długotrwałym i powolnym. Ci uczniowie, którzy mają problem z czytaniem w języku ojczystym, napotykają się na podobne przeszkody podczas nauki czytania w języku obcym (Pamuła 2009: 114). Zatem tekst, na którym pracują powinien być dostosowany do ich możliwości. Nie może być za trudny, ale i za łatwy. Musi stymulować od samego początku (Pamuła 2009: 121). Jeżeli uznamy, że czytanie ma wpływ na rozwój jednostki, bo „kształtuje poczucie jej tożsamości i wyposaża ją w możliwość głębszego rozumienia siebie i świata" (Klus-Stańska 2005: 19), to łatwo zauważyć, że podobne stanowisko zajmują badacze rozważający powiązanie pomiędzy imieniem a budującą się tożsamością dziecka, jak choćby podejście Alloporta (patrz: punkt 4), który akcentuje rolę imienia jako punktu strategicznego pomiędzy rozwijającą się u dziecka organizacja ja, a światem zewnętrznym (Małus 2016: 29), będącego podstawą kształtującej się tożsamości i częścią składową obrazu własnej osoby (Doroszewicz 2003: 105). Metoda Majchrzak łączy wszystkie te teorie przez rozpoczynanie nauki czytania od najważniejszego symbolu jakim dla dziecka jest jego własne imię i stanowi dobry materiał wyjściowy do świadomej percepcji słowa drukowanego.

\section{Emocje - uczenie się - imię}

Znaczenie emocji w procesie dydaktycznym zaczęło dochodzić do głosu w XX wieku. Zauważono wówczas, że są one głównym napędem wszelkich aktywności i od nich zależy efektywność uczenia się. Emocje tworzą zestaw biochemicznych połączeń i reakcji oraz mechanizmów nerwowych wpływających bezpośrednio na stan umysłu. Dąbrowski (2012) powołując się na prace Damasio (2011), LeDoux (1996), Panksepp (1998) stwierdza, że:

Mechanizmy te zajmują stosunkowo wąski zespół rejonów podkorowych, począwszy od poziomu pnia mózgu w górę. Różne rejony mózgu zaangażowane są w innym stopniu w przetwarzanie różnorakich emocji. (...) Wszystkie mechanizmy nerwowe mogą działać automatycznie, bez udziału naszej świadomości, ale poważne i długotrwałe konsekwencje zachodzą dopiero na gruncie świadomego i poznającego umysłu (Dąbrowski 2012: 320).

Do powstawania bądź wygaszania emocji przyczyniają się dwa komponenty: poznawczy oraz oceniający, gdzie pierwszy identyfikuje i percypuje, a drugi nie zawsze świadomie ocenia wartość danego obiektu. Zatem racjonalność, realizm i emocje nie tylko się nie wykluczają, ale wręcz uzupełniają.

Współcześni psychologowie zauważają konieczność rozwijania teorii inteligencji emocjonalnej, spopularyzowanej w latach dziewięćdziesiątych XX wieku przez Daniela Golemana (2000). Jest ona uznawana za nieodzowną w życiu każdego człowieka ze względu na jej związek z wewnętrznymi wartościami, motywacją do 
działań, empatią i umiejętnością komunikowania się. Rozwój inteligencji emocjonalnej ma wpływ na funkcjonowanie ucznia w szkole, który lepiej odczytuje emocje rówieśników i nauczycieli, co sprzyja nabywaniu nowych umiejętności, rozwijaniu problemów poznawczych i tym samym uczeniu się (Matczak i Knopp 2013: 90). Dąbrowski (2012: 332) podkreśla rolę i wpływ emocji na procesy poznawcze, takie jak spostrzeganie, myślenie, uwaga oraz pamięć. Człowiek skupia się i zapamiętuje zwłaszcza wydarzenia i zjawiska o dużym ładunku emocjonalnym. Porównuje brak emocji w postrzeganiu świata do zdjęcia rentgenowskiego, które mimo swej wartości przedstawia schematy i uproszczone elementy danego obiektu. Z kolei, Grzegorzewska (2012: 39) wskazuje na jeszcze inną rolę emocji przyrównując je do filtru, który $\mathrm{w}$ procesie edukacji nadaje dostarczanym informacjom określoną wartość i miejsce w hierarchii przechowywanych wiadomości. Poza tym, w związku z poziomem aktywacji emocji, ich pozytywną lub negatywną wartością oraz orientacją na proces lub osiągnięty wynik, stosuje się trójwymiarową taksonomię emocji osiągnięć. I tak:

Do emocji pozytywnych związanych z aktywacją zalicza się zabawę (orientacja na proces) lub radość, nadzieję, dumę i wdzięczność (orientacja na wynik), natomiast emocje pozytywne związane $\mathrm{z}$ dezaktywacją to relaks (orientacja na proces) lub zadowolenie i ulga (orientacja na wynik) (Grzegorzewska 2012: 40).

Analogicznie, emocje negatywne zorientowane na proces związane z wysoką aktywacją to złość, a z dezaktywacją - nuda. Natomiast emocje zorientowane na wynik są powiązane ze stanem pobudzenia takim jak niepokój, albo z brakiem pobudzenia jak beznadzieja.

Tabela 1. Taksonomia emocji osiągnięć. Opracowanie własne na podstawie Grzegorzewskiej (2012)

\begin{tabular}{|l|l|l|l|l|}
\hline \multirow{2}{*}{ Orientacja } & \multicolumn{2}{|c|}{ Emocje pozytywne } & \multicolumn{2}{c|}{ Emocje negatywne } \\
\cline { 2 - 5 } & \multicolumn{1}{|c|}{ aktywacja } & \multicolumn{1}{c|}{ dezaktywacja } & \multicolumn{1}{c|}{ aktywacja } & \multicolumn{1}{c|}{ dezaktywacja } \\
\hline Na proces & zabawa & relaks & złość & nuda \\
\hline Na wynik & $\begin{array}{l}\text { radość } \\
\text { nadzieja } \\
\text { duma }\end{array}$ & $\begin{array}{l}\text { zadowolenie } \\
\text { ulga }\end{array}$ & $\begin{array}{l}\text { niepokój } \\
\text { wstyd } \\
\text { złość }\end{array}$ & $\begin{array}{l}\text { smutek } \\
\text { rozczarowanie } \\
\text { beznadzieja }\end{array}$ \\
\hline
\end{tabular}

Uwzględniając indywidualny poziom rozwoju dziecka w wieku przedszkolnym, Wygrabek (2014: 127) podkreśla fundamentalną rolę zabawy w procesie nauki czytania. Można zatem wysnuć wniosek, że metody pobudzające pozytywne emocje są równie ważne dla dzieci objętych edukacją wczesnoszkolną, dla których nauka czytania $w$ języku obcym jest podobnie wymagającym zadaniem, tak jak nauka czytania w języku ojczystym dla młodszych dzieci. 


\section{Wnioski}

Analizując związek pomiędzy imieniem i jego ładunkiem emocjonalnym, rozsądnym byłoby wykorzystanie tej wiedzy do propagowania nauki czytania w języku obcym na poziomie edukacji wczesnoszkolnej z wykorzystaniem Odimiennej Metody Nauki Czytania Ireny Majchrzak. Nauka czytania w języku obcym na pierwszym etapie edukacyjnym spychana jest na dalszy plan. Podstawa programowa zakłada rozumienie przez dziecko ogólnego sensu kilkuzdaniowego tekstu pisanego, choć dzieci rzadko mają okazję do jego głębszej analizy. Własne imię oraz imiona kolegów w wersji obcojęzycznej stanowią doskonałą bazę do poznania głosek nie w izolacji, ale w wyrazach ważnych, niosących głębszy sens. Imię oraz później wyrazy bliskie dziecku mogłyby zastąpić sztuczne i pozbawione ładunku emocjonalnego teksty z podręcznika. Dzięki temu praca $\mathrm{z}$ dzieckiem jest zindywidualizowana i oparta na jego predyspozycjach rozwojowych, a elementarzem dla każdego staje się własne imię lub jego wariant w języku obcym.

Oczywiście zasadne wydaje się być pytanie czy przybrane na tę okazję imię niesie taki sam ładunek emocjonalny, co imię metrykalne? Zapewne nie. Z drugiej strony, mimo wszystko, nawet imię przybrane na poczet zajęć lub będące najbardziej zbliżonym fonetycznym odpowiednikiem, jest bardziej spersonalizowanym materiałem edukacyjnym niż takie same wyrazy dla wszystkich uczniów podczas zajęć. Stąd, metoda odimienna stosowana w przedszkolach do nauki czytania w języku ojczystym stanowi atrakcyjną alternatywę do nauki czytania w języku obcym dzieci na poziomie edukacji wczesnoszkolnej. Poszerzanie zasobu słownictwa u dzieci przy jednoczesnym nieuświadomionym wpływaniu na ich wiedzę o języku i rozwijaniu wrażliwości językowej może procentować na kolejnych etapach edukacyjnych. Uzupełniając kompetencje komunikacyjne i pozytywnie wpływając na płynność językową, metoda odimienna oparta na teorii konstruktywistycznej i zastosowana w nauczaniu języka obcego, pozwala skorzystać z zasobów każdego ucznia indywidualnie. Podczas tej samej lekcji, zwłaszcza na trzech pierwszych etapach - „Inicjacji”, „Ściany pełnej liter”, czy „Targu liter” - mimo wykonywania pozornie tych samych zadań, dzieci skupione są na innych aspektach. Analizując wielojęzyczność u dzieci, Kamińska i Kwiatkowska (2009) zwracają uwagę na aspekt, który powinien być zawsze wiodący w nauczaniu języka obcego. Nauka nie może być wymuszona, a powinna być mimowolna i wreszcie poszerzona o źródła językowe i kulturowe. Autorki podkreślają, że „takie podejście jest niezbędne szczególnie w początkowym etapie nauki, gdy dziecko wchodzi w fazę specyficznej alfabetyzacji, ucząc się czytać i pisać w obcym dla siebie kodzie językowym. Wspieranie wzajemnych odniesień pomiędzy językiem macierzystym a językiem drugim (obcym) ułatwia dziecku ich koherencję" (Kamińska i Kwiatkowska 2009: 64). 
Podczas zastosowania elementów metody Ireny Majchrzak w klasie pierwszej w dwujęzycznej szkole podstawowej, zaobserwowałam potencjał tej metody jako środka wzbogacającego tradycyjną naukę. Dzięki niej uczniowie mogą zainteresować się najpierw literami dobrze znanymi, występującymi we własnym, przybranym na poczet zajęć imieniu, by następnie w sposób naturalny we własnym tempie przejść do tych mniej znanych. Dzieci naturalnie zauważają różnice między językiem ojczystym a obcym oraz schemat tworzenia niektórych dźwięków w oparciu o litery. W badanej grupie znajdowały się dzieci od 82 do 93 miesiąca życia, chłopcy i dziewczynki. Wprowadzając poszczególne elementy metody nie zaobserwowałam wpływu wieku lub płci na wynik wykonanych zadań. Problemy z odczytywaniem bądź pisaniem angielskich wyrazów mieli ci sami uczniowie, którzy gorzej radzili sobie również w zakresie edukacji polonistycznej. Natomiast metoda doskonale sprawdzała się wśród uczniów i uczennic nie wykazujących trudności w uczeniu się, dla których nie miała znaczenia również kategoria słów (np. znane z lekcji języka angielskiego / nieznane określające konkretne przedmioty / pojęcia abstrakcyjne). Zaobserwowałam, że w każdej grupie słów znalazły się zadania wykonane na niskim poziomie sukcesu $42-50 \%$, jak również na wysokim poziomie, tj. w granicach $72-79 \%$. Z kolei, dobór słów miał wpływ na wyniki osiągane przez dzieci podczas badania umiejętności pisania. Tutaj rzeczywiście pojęcia abstrakcyjne okazały się największym wyzwaniem i jedynie $43 \%$ badanych prawidłowo wykonało zadanie, polegające na samodzielnym napisaniu poznanych wyrazów.

Nie ulega wątpliwości, że imiona przybrane na poczet zajęć nie niosą tak ogromnego ładunku emocjonalnego, co imiona własne. $Z$ drugiej strony, stają się elementem o wiele bardziej spersonalizowanym niż każdy inny obcojęzyczny wyraz. Poza tym, te same metody stosowane podczas pracy z nauką czytania $\mathrm{w}$ języku ojczystym mają szansę mieć podobne zastosowanie w języku obcym oraz nieść podobne korzyści.

\section{Bibliografia}

Andrzejewska, E. 2010. „Wczesnoszkolne nauczanie języków obcych - polskie prace empiryczne w świetle aktualnych dyskusji o badaniach przyswajania języka obcego przez dzieci”. Neofilolog 35. 131-141.

Brisk, M.E. i M.M. Harrington. 2007. Literacy and bilingualism. Mahwah: Lawrence Erlbaum Associates.

Brzezińska, A. (red.). 1987. Czytanie i pisanie - nowy język dziecka. Warszawa: Wydawnictwa Szkolne i Pedagogiczne.

Brzezińska, A. (red.). 2014. Niezbędnik dobrego nauczyciela. Warszawa: Instytut Badań Pedagogicznych.

Cackowska, M. 1984. Nauka czytania i pisania w klasach przedszkolnych. Warszawa: Wydawnictwa Szkolne i Pedagogiczne.

Czaplicka-Jedlikowska, M. 2008. „Współczesne tendencje kulturowe w nadawaniu imion dzieciom na przykładzie Łobżenicy”. W zbiorze: Dyszak, A.S. (red.). Linguistica Bidgostiana 5. 96-110. 
Czub, M. 2014. Rozwój dziecka: wczesne dzieciństwo. Tom I. Warszawa: Instytut Badań Edukacyjnych.

Dąbrowski, A. 2012. „Wpływ emocji na poznawanie”. Przegląd Filozoficzny. Nowa Seria 3. 83. 315-335.

Damasio, A.R. 2011. Jak umyst zyskat jaźń. Poznań: Rebis.

Doroszewicz, K. 2003. „Psychologiczne aspekty imion ludzkich”. Psychologia Jakości Życia 2. 1. 89-110.

Doroszewicz, K. i M. Krzemińska. 2007. „Forma imienia jako przesłanka wnioskowania o osobowości”. Przeglad Psychologiczny 50. 3. 259-271.

Dziemianko, A. 2015. „Ewaluacja wdrażanej metody Ireny Majchrzak podczas zabaw z dziećmi w przedszkolu". Konteksty Pedagogiczne 1. 4. 143-150.

Goleman, D. 2000. Inteligencja emocjonalna w praktyce. Poznań: Media Rodzina.

Grzegorzewska, I. 2012. „Emocje w procesie uczenia się i nauczania”. Teraźniejszość - Człowiek Edukacja 1. 57. 39-48.

Halik, R. 2010. „Niezwykła moc imienia”. Bliżej Przedszkola 12. 111. 90-91

Hodson, G. i J.M. Olson. 2004. "Testing the generality of the name letter effect: names, initials and everyday attitudes". Personality and Social Psychology Bulletin 31. 8. 1099-1111. online: http://www. stat.columbia.edu/ gelman/stuff_for_blog/hodson.pdf [DW 16.03.2020].

Kamińska, K. i A. Kwiatkowska. 2009. Jesteśmy tacy sami: sztuka w edukacji międzykulturowej. Warszawa: Wydawnictwa Szkolne i Pedagogiczne.

Klus-Stańska, D. 2005. Sensy i bezsensy edukacji wczesnoszkolnej. Warszawa: Wydawnictwa Szkolne i Pedagogiczne.

Koole, S.L. i B.W. Pelham. 2002. "On the nature of implicit self-esteem: the case of the name letter effect". W zbiorze: Spencer, S. i M.P. Zanna. (red.). Motivated social perception: The ninth Ontario symposium. Hillsdale, NY: Lawrence Erlbaum Associates. 93-116.

LeDoux, J.E. 1996. The emotional brain. New York: Simon and Schuster.

Levitt, S.D. i S.D. Dubner. 2005. Freakonomics. HraperCollins e-book.

Majchrzak, I. 1999. Wprowadzenie dziecka w świat pisma. Warszawa: Wydawnictwo Akademickie ŻAK.

Malmquist, E. 1987. Nauka czytania w szkole podstawowej. Warszawa: Wydawnictwa Szkolne i Pedagogiczne.

Małus, A. 2016. „Znaczenie osobiste przypisywane imieniu”. (Personal meanings attributed to a name). Psychiatria i Psychoterapia 12.1.25-42.

Matczak, A. i K.A. Knopp. 2013. Znaczenie inteligencji emocjonalnej w funkcjonowaniu człowieka. Warszawa: Wydawnictwo Stowarzyszenia Filomatów Redakcja Liberi Libri.

Metera, H. 1978. „Uwarunkowania nauki czytania”. Oświata i Wychowanie 8. 25-31.

Mystkowska, H. 1979. Uczymy czytać w przedszkolu. Warszawa: Wydawnictwa Szkolne i Pedagogiczne.

Olejnik, D. 2001. „Kształtowanie umiejętności czytania w edukacji wczesnoszkolnej”. Nauczyciel i Szkoła 1-2. 10-11.63-66.

Pamuła, M. 2009. „Trudna sztuka czytania w języku obcym”. W zbiorze: Sikora-Banasik, D. (red.). Wczesnoszkolne nauczanie języków obcych. Warszawa: Centralny Ośrodek Kształcenia Nauczycieli. $110-126$.

Panksepp, J. 1998. Affective neuroscience: the foundations of human and animal emotions. Oxford/New York: Oxford University Press.

Postoła, A. 2012. „Klątwa Dżastina, czyli magia imion”. Rzeczpospolita, publikacja 04.04.2012. online: https://www.rp.pl/artykul/854602-Klatwa-Dzastina--czyli-magia-imion.html_[DW 02.02.2020]

Samochowiec, A., Wojciechowski, B. i J. Samochowiec. 2004. „Rola myślenia magicznego w obronie przed lękiem". (The role of magical thinking in defence against anxiety). Psychiatria 1. 1. 17-22. 
Sikora-Banasik, D. (red.). 2009. Wczesnoszkolne nauczanie języków obcych. Warszawa: Centralny Ośrodek Kształcenia Nauczycieli.

Spencer, S. i M.P. Zanna. (red.). 2002. Motivated social perception: The ninth Ontario symposium. Hillsdale, N.J.: Lawrence Erlbaum Associates.

Szczerbowska-Kopacz, J. 2011. „Klasyfikacja, znaczenie oraz pochodzenie nazw geograficznych w Polsce". Językoznawstwo: wspótczesne badania, problemy i analizy językoznawcze 5. 177-184.

Tinker, M.A. 1980. Podstawy efektywnego czytania. Warszawa: Wydawnictwa Szkolne i Pedagogiczne.

Wieszczeczyńska, E. 2007. Wczesnoszkolna edukacja językowa a nauczanie czytania. Problem alfabetyzacji w jezzku niemieckim jako obcym na przyktadzie wybranych metod i elementarzy. Wrocław: Oficyna Wydawnicza ATUT.

Wygrabek, L. 2014. „Alternatywne metody nauki czytania u dzieci w wieku przedszkolnym”. Zaszyty Naukowe Wyższej Szkoty Humanitas. Pedagogika 9. 123-136.

Zagórski, S. 2010. „Ja kontra Maryla Rodowicz”. Gazeta Wyborcza, publikacja 28.09.2010. online: http://wyborcza.pl/175400,8435321,Ja_kontra_Maryla_Rodowicz.html [DW25.03.2020]. 